\title{
Integrating ICT in English for Academic Purposes Materials through Task-Based Approach
}

\author{
https://doi.org/10.3991/ijet.v14i17.10753 \\ Audi Yundayani $(\bowtie)$ \\ STKIP Kusuma Negara, Jakarta, Indonesia \\ audi yundayanilstkipkusumanegara.ac.id \\ Dian Kardijan \\ Universitas Siliwangi, Tasikmalaya, Indonesia \\ Tutut Herawan \\ AMCS Research Center, Yogyakarta, Indonesia
}

\begin{abstract}
English communication is a crucial skill that should be mastered by students at the university level due to the demand of study skills comprehension. Nevertheless, students still have low motivation and lack of practicing English proficiency as substantial ability in academic field. This condition is strengthened by the limited owing to the required time in English for Academic Purposes (EAP) classes. Covering the ongoing situation, information and communications technology (ICT) presents a virtual educational setting that is able to provide accessible effective materials to assist participants in learning. In addition, the task-based approach is taken based on the students' need to practice authentic English through meaningful tasks. This study aims at analyzing the students' perceptions on the implementation of integrating ICT into EAP materials through a task-based approach and identifying the implications. We employ descriptive qualitative method, where a survey was carried out to obtain some information about the students' viewpoint regarding the materials. This result reveals that the practice of integrating ICT into English Academic Purposes (EAP) materials through task-based approach promotes students' motivation and gains meaningful learning experiences.
\end{abstract}

Keywords-EAP materials; ICT; Task-based approach.

\section{Introduction}

English is a compulsory subject that should be taken by the students of non-English education study programs. At the university level, English for specific purposes (ESP) teaching must be focused on literacy skills relevant and appropriate to the purposes of discipline field, particular understandings of academic and professional communities [1] [2]. In addition, English mastery is a must in order to support the learning process which is in line with each discipline. The ESP focuses on the specific communicative needs and practices of academic experts [3] [4]. EAP, as a branch of ESP, provides 
students with proper English skills that are required in a tertiary level study or college level, including the way of presenting, researching, and publishing in the academic field [5] [6]. It concerns with the English skills which are required for study purposes in higher education. It relates to a particular academic subject and it is known as the study skills that concerns with the application for the more mechanical aspects of a study.

In addition, students' motivation plays an important role in the success of achieving the learning goals. It is related to students' willingness to put forth effort on the English learning process. Unfortunately, many students of non-English study program still have problems in developing their English learning motivation. As a consequence, they have low competencies in using English communicatively. Their experience in using English is very low. On the other hand, they have lacked in practicing English skills. These phenomenons are challenge for ESP teachers to find out the suitable materials and ways in teaching learning process. Furthermore, teaching and learning English for academic purposes is not an easy task both for the educators and students of non-English education study programs. English practices in ESP classes are limited owing the time required to do so and that ESP students may need more time to support while English practicing. English ability is a critical skill for students in higher education, mainly ESP students since they are constantly expected to present their discipline and purpose-specific research studies in the form of reports, proposals, and presentations. Hyland and Hamp-Lyons [7] believe that the heart of ESP is tailoring instruction to specific rather than general learning purposes. Owing to some of achieving the ESP learning goals, it needs English materials that appropriate with discipline study. Adel and Enayat [8] stated that materials should be made aware of the potential social impact of the texts and images they use in ESP textbooks.

Task-based approach is viewed as the expansion of communicative language teaching (CLT). It allows English students to motivate themselves by evolving their English competence through the interaction and meaningful activities [9] [10]. A task is given as a tool for students to communicate by practicing the target language. Language is not only about grammatical rules, phonology or the lexical that should be memorized. Language is believed as the action. The end task should improve students' self-confidence and as the impact, students motivated. Educators have an important role to select the relevant tasks that make students have social contact and mutual rapport between them. Nunan [11] asserts that the principles and practices of task-based language teaching are include

- A needs-based approach to content selection

- Focus on learning to communicate through interaction in the target language

- Authentic texts introduction into learning situation

- Opportunities to focus not only on language but also on the learning process

- The increment personal experiences to the classroom learning

- The linking of classroom language learning with the language using in the real situation. The principles of task-based approach are in line with the ESP approach. 
Both are focused on students' needs, communicative and applicative language ability, and authentic and meaningful activities.

The use of authentic data in the task-based materials should be interested point. It makes students have a chance to connect naturally with English items in contexts. Task-based materials use authentic data for the learning activities and empower students to do the real-world tasks that naturally occur in the world through the language. This reflects the idea that students acquire language by using it, so it is important by the educators to provide the opportunities for students to use language communicatively and practically. As the consequences, educators should be able to design learning materials that can meet students' needs and characteristics conforming to the learning objective. Shi \& Nunan [12] believed that a task-based material is successful in language learning since the students learn best by doing. In addition, students will gain some language experiences in interaction with other.

In the current situation, ICT known as information and communications technology becomes a very important means in language teaching. It has the ability to transform some aspects at ELT development [13] [14]. It offers many current opportunities for access to a wealth of ready-made ELT materials. In addition, ICT provides ease for educators in teaching process through several new ways as well as for students to keep some materials [15] [16] [17] [18]. ICT is viewed as a technological tools that are able to make the situation of English learning becomes creative and interactive [19] [20]. It gives students' exposure to practice in four main aspects of language skills - listening, speaking, reading and writing. For instance, many kinds of ICT media genres can be applied in English learning such as animations, digital texts, videos, audios, or the combination of those media known as multimedia. Tinio [21] believes that ICT provides students with digital age literacy, high productivity, inventive thinking, higher-order thinking, sound reasoning, and effective communication. In addition, ICT and English have become essential literacy skills for a growing number of non-native speakers of English to ensure full participation in the information society [22]. There is no a doubt that ICT utilizing considered as an impressive learning media to be used in the arena of modern language education. It is anurgency that gives life to a different viewpoint on how language is effectively taught and learned.

Concerning this study, researchers believed that the use of authentic EAP materials are given through task based approach and being used in technologically mediated contexts providing the opportunities for students to use language communicatively and practically. The Figures 1 and 2 below show how EAP Materials through a taskbased approach is integrated into ICT. 


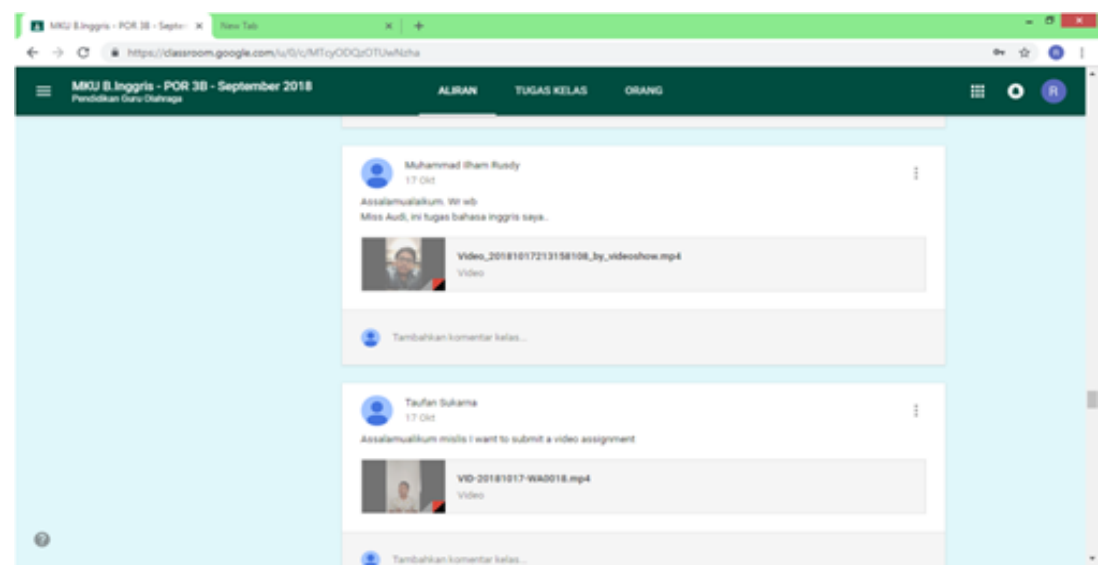

Fig. 1. The Profile of Integrating ICT into English EAP Materials Through Task-based Approach - Video

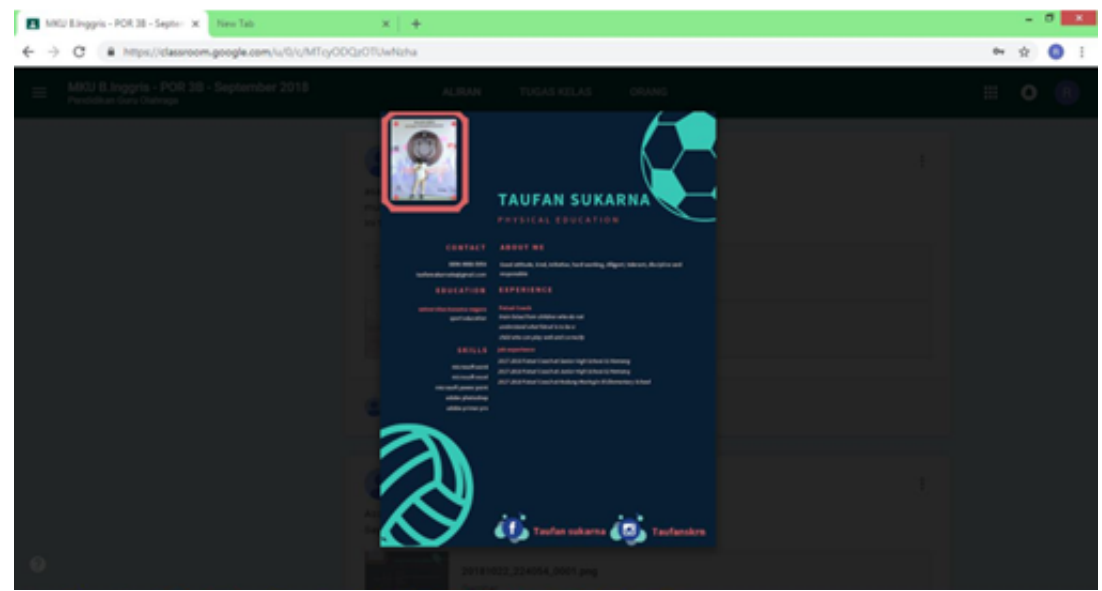

Fig. 2. The Profile of Integrating ICT into EAP Materials Through Task-based Approach Canva

In applying the ICT in the English learning process, educators should pay attention to the four key stages that cover

- Testing the right instructional technology

- Determining the learning outcomes (competencies should be achieved)

- Identifying learning experiences and customize it with the available technology

- Preparing the learning experience to be presented online. Simonson's stages should be as a guidance in providing the suitable materials in line with the students' need in performing the English meaningful activities [23]. It is a must for the educators to make sure that the ICT using refers to the English learning objectives. In addition, the ICT should be accessible and in line with the students' characteristics 
including needs. It is important to make sure that the studentshave the meaningful learning experiences and by the end,it gives the positive impact to the English competence.

The ICT use has the potential to change the students' paradigm towards English learning. As the component of the instructional strategy, the use of ICTgives positive impact in motivating the students. The challenge of the ICT using is the ICT's appeal and students' interest. The ARCS model, developed by John Keller, offers four features that must be considered in designing the instructional strategy i.e.

- Attention

- Relevance

- Confidence

- Satisfaction [24]

The attention should be gained by the students through their positive attitudesby asking questions, giving interaction and creating mental challenges. It can be seen as the combination between behavioral and cognitive process. It describes students' arousal of doing something. Relevance is known as something that caused students' interest when they perceive the pertinence of something they get with their needs.Students feel a connection between their expectation and what they get. Being confidence is a feeling of belief that students are able to pursue the learning objectives. It likes a firm trust that satisfaction relates with a pleasant feeling that students get when they receive something they wanted, or when they have done something they wanted to do. It is not always related to the reward.

The objective of this study is to describe the students' perceptions on the practice of integrating ICT into EAP materials through task-based approach. Furthermore, we identify the implications of the perseprions. Therefore, the following questions were addressed in this study,

How are the students' perception on the practice of integrating ICT into EAP materials through a task-based approach?

What are the implications of the practice EAP materials through task-based approach which is given in technologically mediated contexts?

The rest of this paper is organizefd as follow. Section 2 describes the proposed method. Section 3 presents the obtanied results and following by discussion. Finally, Section 4 concludes this work.

\section{Methodology}

\subsection{Research method}

This qualitative study employs a descriptive-exploratory design. It explores the participants' understandings of underlying reasons, opinions, and motivation on a certain theme. This kind of research method provides insights into the problem and 
helps develop ideas. Wyse [25] stated that qualitative research can be used to uncover trends in thoughts and opinions, and delve deeper into the problem investigated.

\subsection{Instruments}

In order to collect students' voice on the practice of integrating ICT into EAP materials through task-based approach, two research instruments were utilized. The first one was a standardized survey questionnaire adopted by the researchers from Keller model which aims to benchmark the practice on ICT into EAP materials through task-based approach by surveying at non-English education study programs students on their opinions and attitudes of ICT using in EAP materials. To align the survey-questionnaire with the objectives of the present study, the researcher purposively modified some of the items in the instrument. To get the deeper consideration, the researcher drafted semi-structured interview questions validated by two experts in the field.

\subsection{Procedure}

In total, 40 non-English education study programs students were asked to complete the adopted survey questionnaires. Next, the researchers asked for a separate interview session with two subjects following the questions in the semi-structured interview guide. Each of the interview sessions lasted for about 30 minutes, with the researchers comparing the responses of the subjects from the survey questionnaire and their answers on the questions provided in the semi-structured interview. After collecting the data, the researchers analyzed, established, and described the finding of the practice EAP materials through task-based approach in technologically mediated.

\section{$3 \quad$ Findings and Discussions}

The research finding was taken from the survey questionnaire responses and a semi-structured interview. The relevant discussions were based on the elements provided in the survey questionnaire. These parts from the instrument are broken down as

- Attention

- Relevance

- Confidence

- Satisfaction

The personal background information of the respondents sustains the findings. Table 1 presents the personal background information of the respondents that were considered relevant in this study. 
Table 1. Personal Background Information

\begin{tabular}{|l|l|c|}
\hline \multirow{2}{*}{ Gender } & Female & $22(55 \%)$ \\
\cline { 2 - 3 } & Male & $18(45 \%)$ \\
\hline \multirow{2}{*}{ Age } & Less than 20 y.o & $13(32.5 \%)$ \\
\cline { 2 - 3 } & $21-30$ y.o & $27(67.5 \%)$ \\
\hline Number & 40 students \\
\hline
\end{tabular}

The Table 1 above described the composition of the respondents. The main information showed that all of the students came from millennial and generation $\mathrm{Z}$, in the age between 18 to 30 years old. It described that the students are digital natives since they have grown up in experiencing digital technology in all their lives. Mainly they prefer to use electronic and digital technologies for doing the interpersonal communication. These findings are in line with Bilgiç, et al. [26] who believed that digital native refers to anyone who grows up using technology, and who thus feels comfortable and confident with it. This students' characteristic should be known by the teachers as the instructional designer to choose the suitable learning tools, including the appropriate media that can be integrated in the learning process. ICT using gives the positive impacts on students' enthusiasm into learning English. It is in line with students' characteristics as the digital native. The use of ICT for the language learning process can be seen as a must.

Figure 3 below informs the students' perception on the practice integrating ICT into EAP materials through task-based approach for the attention component.

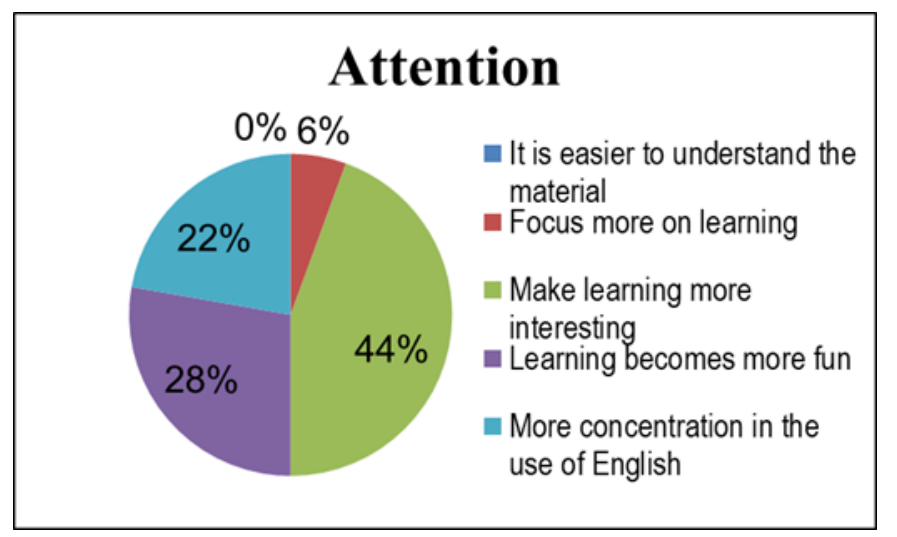

Fig. 3. Students' response on the aspect of attention

The Figure 3 above shows the students' response concerning with the attention component. Almost $44 \%$ of students believe that the integrating ICT into EAP materials through task-based approach makes the English learning process becomes more interesting. 28\% of students feel that the ICT using makes English learning becomes more fun. $22 \%$ of students see the ICT can make them easier to understand the materials and $6 \%$ of them feel more focus on learning through the ICT. 
The findings describe the positive impact of grabbing students' attention by giving the appropriate stimulus in the learning process. The stimulus was taken from the ICT as a media in the learning process in the form of video, PB-works, Canva, PowToon, etc. As the result, students who are motivated to engage in the learning process show their effort, interest, and persistence when they face challenges [27]. Attitudes appear into actions and students with motivation to learn probably to be more successful in doing so and are more likely to retain information beyond a class session. Malik [28] strengthened these findings by stating that grabbing attention initiates the motivation for the students. Once students are interested in a topic, they are willing to pay attention, invest their time, and find out more.

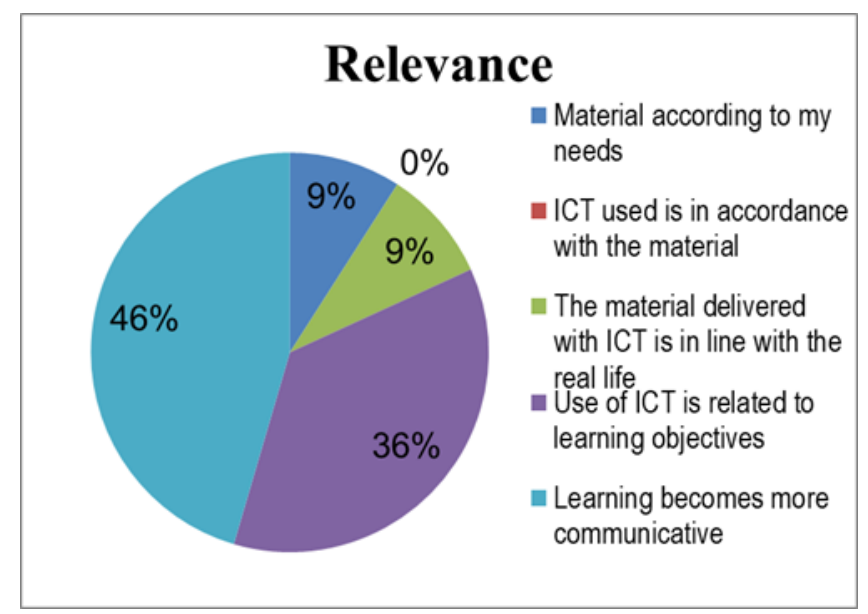

Fig. 4. Students' response on the aspect of relevance

The second aspect of the ARCS model is the aspect of relevance. The Figure 4 above describes that $46 \%$ of students feel that English learning becomes more communicative after ICT applied in the learning process. About $36 \%$ of students believe that the use of ICT is related to learning objectives. About $9 \%$ of students think that the materials delivered by ICT are in line with real life. About $9 \%$ of students admit that English learning becomes more communicative through the ICT using.

The findings show the relevance aspect of the students' perspective. The relevance can come from the students' feeling about the value of the given materials through the ICT according to their needs. In another hand, being relevance can be seen from the improved ability or the learning process. The relevance material is one of the important aspects of creating good atmosphere of the learning process. The practice of integrating ICT in EAP task-based material has a positive impact by initiating the authentic and meaningful learning process. This finding in line with a statement from Jonassen, et al. [29] who state that the main benefit of ICT to language learning is that it can make meaningful learning as active, authentic and cooperative.

The relevance of ICT relates to students' feeling and thinking. It can be seen in the areas of: 
- What is learned?

- How it is learned?

- When it takes place?

- Where it takes place?

- Who is learning

- Who is teaching?

Oliver [30] concluded that the impact will grow considerably in years to come and that ICT will become a strong agent for change among many educational practices.

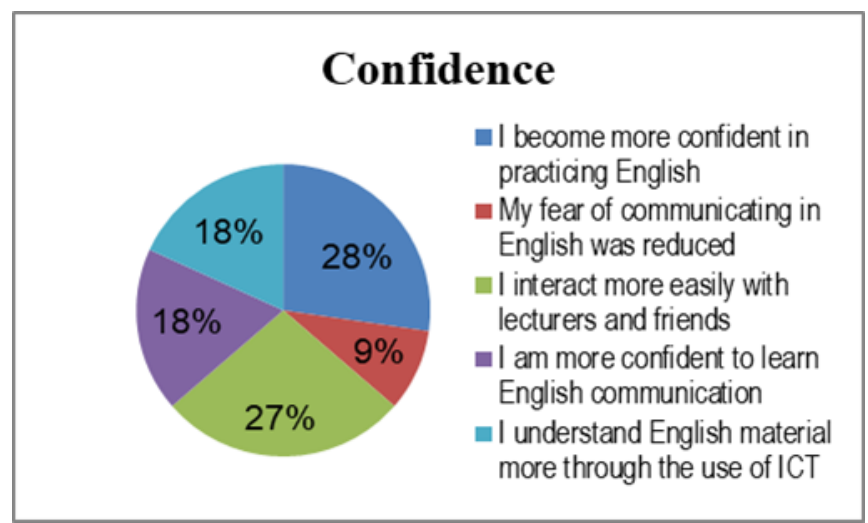

Fig. 5. Students' response on the aspect of confidence

From Figure 5 above, concerning the confidence aspect, it shows $28 \%$ of students proved they become more confident to learn English materials given. Furthermore, $27 \%$ of students' opinion shows that they can interact with lecturers and friends easily. $18 \%$ of students' response states they feel more understand and also confident in English communication. Meanwhile, 9\% of students feel not fear in practicing English communication. Collected data describe the positive effect of ICT using on students' confidence in developing English skill. They can more explore in understanding the EAP materials. ICT offers students a lot of time in discovering the mechanics of EAP materials content. It also changes the relationship between lecturer and student in the teaching and learning process. Students' confidence will arise when they are able to communicate and discuss the materials with their lecturer and friends. Therefore, integrating ICT into materials have changed students' confidence for practicing English better in several ways, such as readiness to spend more time exploring material content [31] [32] [33].

The confidence aspect confirms positive expectations to achieve students' success and it relates to students' motivation and students' effort in reaching their performance target. The use of ICT could motivate students' confidence to express their thought freely in practicing English and it could support the students' responsibility to do some tasks that given [34]. For this reason, teachers should provide the whole learning component by estimating students' probability in achieving their success. 


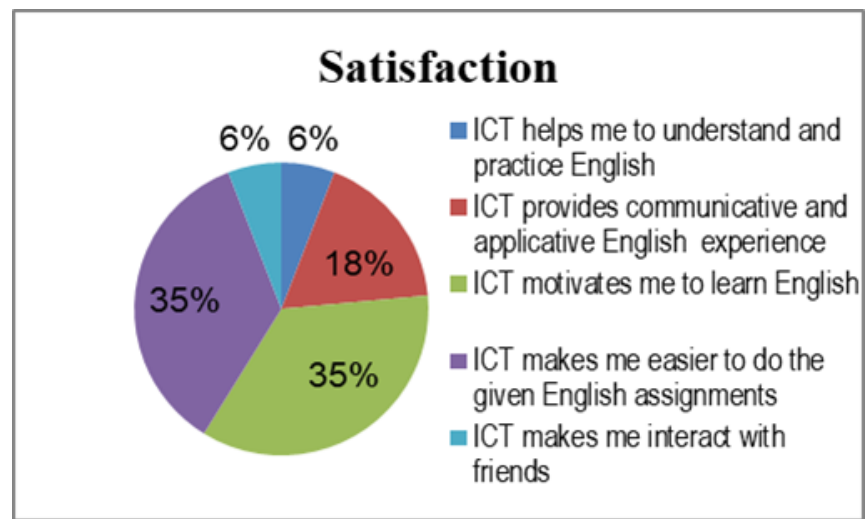

Fig. 6. Students' response on the aspect of satisfaction

From Figure 6 above, it can be concluded that sstudent's realize the importance of English skill to support their study successful. However, they are faced difficult in improving English skill that related with the need of study discipline background. The use ICT as a tool in teaching and learning process has given chance for students to be more interest to practice English communicatively. It showed the students' satisfaction while engaging ICT in practicing English, the following students' opinion; 35\% of students' satisfaction which is ICT could facilitate easier to fulfill English assignment given and $6 \%$ of students' feel that ICT can be helped in understanding and practicing English, as well as facilitate to interact with their classmate. Furthermore, $18 \%$ of students' believe that ICT used gives experience itself in practicing English as communicative and applicative.

The findings show that students' satisfaction is dominant. They feel good to have the ICT integrated EAP materials through task-based approach. It can be seen from their enthusiasm, sense of achievement, praise from a higher-up, etc. The important element to know students' satisfaction is through the students' feedback including an appreciation for the result. It is important for the lecturers to find the students' satisfaction by evaluating students' performance and allowing them to apply their newly learned skills. These findings in line with Keller's [35] suggestion through three main strategies:

- Encouragement

- Provide positive reinforcement and motivational feedback

- Maintain consistent standards and consequences for success

The encouragement can be happened by inviting the students to provide testimonials on how materials through the ICT supported them in the learning process. Lecturers are able to give positive reinforcement and motivational feedback by giving awards certificates to students as they master the complete set of skills

ICT can be used to enhance students' learning experience. They can learn more effectively by the collaboration to discuss materials together and also they feel more comfortable in doing or finishing the assignments in satisfaction [36] [37] [38]. Fur- 
thermore, the ICT tools recognize and improve students' self-esteem, vocational preparedness, language proficiency, learning autonomy and in addition they provide immediate feedback [39] [40]. Students must capable using English communicatively, thus existing ICT has constructed students learning independence, task orientation that related to understand and practice English easily. Maintaining consistent standards and consequences for success can be applied by the lecturers through providing evaluation feedback after the assignment has been completed.

The application of technological resources in the language learning processes equips a good source of authentic situations to practice the language through collaborative learning. Muchtar [41] strengthened this statement by stating that technology serves as a bridge to higher achievement by engaging students in relevant and meaningful learning. In addition, Butler-Pascoe and Wiburg [42] issued seven important ICT involvement in the second language learning environment:

- It provides interaction, communicative activities, and real audiences

- It supplies comprehensible input

- It uses task-based and problem-solving activities

- It facilitates focused development of English language skills

- It uses multiple modalities to support various learning styles and strategies

- It meets the affective needs of students

- It fosters understanding and appreciation of the target and native cultures.

Those describe the functions of ICT in enhancing second language learning. Students believe that ICT-based activities can apply a wide variety of opportunities to improve second language learning skill. Furthermore, Eckhaus [43] stated that students responded with only positive reactions to case relevance, course content and materials, technology implementation, and facilitation by teachers. These findings should be highligthed by the EAP teacher in providing and delivering the learning process based on students' requirement, including their characteristic and the limitation of EAP class.

\section{Conclusion}

ICT can be used to increase students' learning motivation. They can learn more successfully to practice materials and also they feel more comfortable by the collaboration to discuss materials together.The ICT advancements provide the way to solve the students' problem in English learning disengagement and they have a potential to enhance students' motivation, trust and skills by providing them some opportunities for practice the English language. The ICT using is in line with the essence of ESP and task-based approach that focus on practical and meaningful activities relate to students' real life. Students agree that the major influence on the students' motivation to learn English is through the integrating ICT into EAP taskbased materials. They tend to be motivated to engage in an activity if it is perceived to be linked to the satisfaction of personal aspect. 
It is expected that this research will increase the existing knowledge of EAP study in international literature, especially in the practice of integrating ICT into EAP materials through a task - based approach taken from the voice of students. The current research presented students' viewpoint in ICT using related with pedagogical field. The research findings challenged the suspicions of some scholars about the practice of integrating ICT into EAP materials through a task - based approach.

\section{$5 \quad$ References}

[1] Hyland, K. (2002). Specificity revisited: how far should we go now? English for Specific Purposes, 21(4), 385-395. https://doi.org/10.1016/s0889-4906(01)00028-X

[2] Mukminin, A., Ali, R. M., \& Ashari, M. J. F. (2015). Voices from within: Student teachers' experiences in English academic writing socialization at one Indonesian teacher training program. The Qualitative Report, 20(9), 1394-1407.

[3] Hyland, K. (2016). The Routledge Handbook of English for Academic Purposes. Routledge.

[4] Johns, A. M., \& Dudley-Evans, T. (1991). English for Specific Purposes: International in Scope, Specific in Purpose. TESOL Quarterly, 25(2), 297. https://doi.org/10.2307/3587465

[5] Douglas, S. R., \& Kim, M. (2015). Task-Based Language Teaching and English for Academic Purposes: An Investigation into Instructor Perceptions and Practice in the Canadian Context. TESL Canada Journal, 31, 1. https://doi.org/10.18806/tesl.v31i0.1184

[6] Yundayani, A., Emzir, E., \& Rafli, Z. (2017). Need Analysis: The Writing Skill Instructional Material Context for Academic Purposes. English Review: Journal of English Education, 6(1), 59. https://doi.org/10.25134/erjee.v6i1.771

[7] Hyland, K., \& Hamp-Lyons, L. (2002). EAP: issues and directions. Journal of English for Academic Purposes, 1(1), 1-12. https://doi.org/10.1016/s1475-1585(02)00002-4

[8] Adel, S. Mohammad Reza \& Enayat, Mostafa Janebi. (2016). Gender Representation and Stereotyping in ESP Textbooks. ASIAN ESP Journal. 12(3), 94-119.

[9] Ellis, R. (2003). Task-Based Language Learning and Teaching. Oxford University Press.

[10] Willis, D., \& Willis, J. (2001). Task-based language learning. The Cambridge Guide to Teaching English to Speakers of Other Languages, 173-179. https://doi.org/10.1017/cbo $\underline{9780511667206.026}$

[11] Nunan, D. (2004). Task-Based Language Teaching. Ernst Klett Sprachen, 2006.

[12] Shi, L., \& Nunan, D. (2000). Second Language Teaching and Learning. TESOL Quarterly, 34(2), 369. https://doi.org/10.2307/3587962

[13] Schmid, E. C. (2010). Bringing Technology into the Classroom. ELT Journal, 65(1), 8991.

[14] Dudeney, G., \& Hockly, N. (2012). ICT in ELT: how did we get here and where are we going? ELT Journal, 66(4), 533-542. https://doi.org/10.1093/elt/ccs050

[15] Hismanoğlu, M. (2011). The integration of information and communication technology into current ELT coursebooks: a critical analysis. Procedia - Social and Behavioral Sciences, 15, 37-45. https://doi.org/10.1016/j.sbspro.2011.03.048

[16] Warschauer, M. (2013). Technological change and the future of CALL. In New perspectives on CALL for second language classrooms (pp. 27-38). NY: Routledge.

[17] Uerz, D., Volman, M., \&Kral, M. (2018). Teacher Educators' Competences in Fostering Student Teachers' Proficiency in Teaching and Learning with Technology: An Overview of Relevant Research Literature. Teaching and Teacher Education, 70, 12-23. https://doi.org/10.1016/j.tate.2017.11.005 
[18] Sosa Neira, E. A., Salinas Ibáñez, J. M., \& De Benito Crosetti, B. (2018). Model of Incorporation of Emerging Technologies in the Classroom (MIETC). International Journal of Emerging Technologies in Learning, 13(06), 124. https://doi.org/10.3991/ijet.v13i06.82 26

[19] Mostmans, L., Vleugels, C., \& Bannier, S. (2012). Raise your hands or hands-on? The role of computer-supported collaborative learning in stimulating intercreativity in education. Journal of Educational Technology \& Society, 15(4), 104.

[20] Lee, J., \& Bonk, C. J. (2016). Social network analysis of peer relationships and online interactions in a blended class using blogs. The Internet and Higher Education, 28, 35-44. https://doi.org/10.1016/j.iheduc.2015.09.001

[21] Tinio, V. L. (2002). Survey of Information \& Communication Technology Utilization in Philippine Public High Schools. Retrieved on April, 15, 2008.

[22] Jung, S. (2006). Information and Communication Technology Use and Skills (ICTUS) for learning English. Doctoral dissertation, University of Maryland.

[23] Santo, S. A. (2011). Teaching and Learning at a Distance: Foundations of Distance Education. American Journal of Distance Education, 25(3), 201-204. https://doi.org/10. 1080/08923647.2011.589757

[24] Dick, W., Carey, L., \& Carey, J. O. (2005). The systematic design of instruction. 8th Edition. NJ: Pearson

[25] Wyse, S. E. (2011). What is the difference between qualitative research and quantitative research? Snap surveys, 16-1.

[26] Bilgiç, H. G., Doğan, D., \& Seferoğlu, S. S. (n.d.). Digital Natives in Online Learning Environments. Advances in Higher Education and Professional Development, 192-221. https://doi.org/10.4018/978-1-5225-0039-1.ch009

[27] Schunk, D. H., \& Usher, E. L. (2012). Social Cognitive Theory and Motivation. Oxford Handbooks Online. https://doi.org/10.1093/oxfordhb/9780195399820.013.0002

[28] Malik, S. (2014). Effectiveness of Arcs Model of Motivational Design to Overcome NonCompletion Rate of Students in Distance Education. Turkish Online Journal of Distance Education, 15(2). https://doi.org/10.17718/tojde.18099

[29] Jonassen, D., Mayes, T., \& McAleese, R. (1993). A Manifesto for a Constructivist Approach to Uses of Technology in Higher Education. Designing Environments for Constructive Learning, 231-247. https://doi.org/10.1007/978-3-642-78069-1 12

[30] Oliver, R. (2002). The role of ICT in higher education for the 21 st century: ICT as a change agent for education. Retrieved from https://wenku.baidu.com/view/ab4dea6cb84ae $45 \mathrm{c} 3 \mathrm{~b} 358 \mathrm{c} 58 . \mathrm{html}$

[31] Padurean, A., \& Margan, M. (2009).Foreign language teaching via ICT. Revista de Informatica Sociala, 7(12), 97-101.

[32] Yang, J. C., Chen, C. H., \& Chang Jeng, M. (2010). Integrating video-capture virtual reality technology into a physically interactive learning environment for English learning. Computers \& Education, 55(3), 1346-1356. https://doi.org/10.1016/i.compedu.2010.06. $\underline{005}$

[33] Fu, J. S. (2013). ICT in education: A critical literature review and its implications. International Journal of Education \& Development using Information \& Communication Technology, 9(1).

[34] Young, S. S. C. (2003). Integrating ICT into second language education in a vocational high school. Journal of Computer Assisted Learning, 19(4), 447-461. https://doi.org/10.10 46/j.0266-4909.2003.00049.x

[35] Keller, J. M. (2009). The Arcs Model of Motivational Design. Motivational Design for Learning and Performance, 43-74. https://doi.org/10.1007/978-1-4419-1250-3 3 
[36] McNair, V., \& Galanouli, D. (2002). Information and communications technology in teacher education: can a reflective portfolio enhance reflective practice? Journal of Information Technology for Teacher Education, 11(2), 181-196. https://doi.org/10.1080/ 14759390200200131

[37] Lu, Z., Huang, X., \& Sun, J. (2008). The Teacher's Roles in a Student-Centered AudioVideo Speaking Class. International Journal of Pedagogies and Learning, 4(4), 78-95. https://doi.org/10.5172/ijpl.4.4.78

[38] Sumtsova, O. V., Aikina, T. Y., Bolsunovskaya, L. M., Phillips, C., Zubkova, O. M., \& Mitchell, P. J. (2018). Collaborative Learning at Engineering Universities: Benefits and Challenges. International Journal of Emerging Technologies in Learning, 13(01), 160. https://doi.org/10.3991/ijet.v13i01.7811

[39] Liu, M., Moore, Z., Graham, L., \& Lee, S. (2002). A Look at the Research on ComputerBased Technology Use in Second Language Learning. Journal of Research on Technology in Education, 34(3), 250-273. https://doi.org/10.1080/15391523.2002.10782348

[40] Zhang, D., \& Wang, X. (2017). The Effects of the CALL Model on College English Reading Teaching. International Journal of Emerging Technologies in Learning, 12(12), 24. https://doi.org/10.3991/ijet.v12i12.7954

[41] Muchtar, N. (2018). The Effects of Multimedia Technology on Electrical Engineering Students' Reading Achievement. ASIAN ESP Journal. 14(6), 86 - 94.

[42] Lin, L.L. (2009). Technology and Second Language Learning. Online Submission. Retrieved from: https://files.eric.ed.gov/fulltext/ED505762.pdf

[43] Eckhaus, R. (2018). Supporting the adoption of business case studies in ESP instruction through technology. ASIAN ESP Journal. 14(7.2), 280 - 298.

\section{Authors}

Audi Yundayani is a lecturer in English education program at STKIP Kusuma Negara, Jakarta, Indonesia. She has always been interested in researching how to explore the area of ESP. She has obtained a doctorate degree in Language Education Program from Universitas Negeri Jakarta, Indonesia. Her academic interests include ESP practices, applied linguistics including teaching English as a foreign language. She has presented and published nationally and internationally on issues related to her main area of research interest. She has a background in designing English writing material for academic purposes.

Dian Kardijan serves as an English education lecturer at Universitas Siliwangi, Tasikmalaya, Indonesia. He received a doctorate degree in Language Education Program from Universitas Negeri Jakarta, Indonesia. His dissertation deals with responsive evaluation linked to the program implementation of English learning for hospitality specific purposes. His major area of research interests includes ESP practices and language materials evaluation and design. He has published couples of papers in his areas of interests. He has also participated in several national and international language conferences. E-mail: diankardijan@unsil.ac.id

Tutut Herawan is a senior researcher at AMCS Research Center, Indonesia. Formerly he is an associate professor at Department of Information Systems, University of Malaya. He received $\mathrm{PhD}$ degree in information technology in 2010 from Universiti Tun Hussein Onn Malaysia. He is a visiting researcher at Parallel and Distributed 
Computing Research Lab of Deakin University Australia. He is also a part-time lecturer in many universities in Indonesia. He has more than 12 years experiences as academic and successfully supervised five $\mathrm{PhD}$ students. He presently supervises 15 Master \& PhD students and has examined Master \& PhD Theses. He is the executive editor of Malaysian Journal of Computer Science (ISI JCR with IF 0.405). He has also guest edited many special issues in many reputable international journals. He has edited five Springer-series books and published more than 270 articles in various book chapters, international journals and conference proceedings which are indexed in Scopus database (with H-index 22). He is an active reviewer for more than 50 international journals including top flagships journal e.g. IEEE Transactions on Fuzzy Systems, Knowledge-Based Systems, Information Sciences, IEEE Access, and many more. He delivered more than 20 keynote addresses, invited workshop and seminars and has been actively served as a chair, co-chair, program committee member and coorganizer for numerous international conferences/workshops. He is the founding chair of SCDM \& DaEng conferences with are supported by the renowned publisher Advances in Intelligent System \& Computing and Lecture Notes in Electrical Engineering of Springer Verlag, respectively. His research area includes information retrieval and decision support in information systems. His research area includes Data Mining and Knowledge Discovery, Decision Support in Information System, Rough and Soft Set theory. E-mail: tututherawan@stkipkusumanegara.ac.id

Article submitted 2019-04-28. Resubmitted 2019-06-15. Final acceptance 2019-06-19. Final version published as submitted by the authors. 